\title{
Review* \\ Metabolic factors affecting the reproductive axis in male sheep
}

\author{
Dominique Blache ${ }^{1}$, Lucia M. Chagas ${ }^{1,2}$, Margaret A. Blackberry ${ }^{1}$, \\ Philip E. Vercoe ${ }^{1}$ and Graeme B. Martin ${ }^{1+}$ \\ ${ }^{1}$ Faculty of Agriculture (Animal Science), University of Western Australia, Nedlands, WA 6907, Australia; and \\ ${ }^{2}$ Dairying Research Corporation, PB 3123, Hamilton, New Zealand
}

\begin{abstract}
Changes in food intake affect the reproductive axis in both sexes, and the nutritional signals involved and the sites that receive those signals are now beginning to be unravelled. Our studies have focussed on the mature male sheep, a model in which high food intake stimulates $\mathrm{GnRH}-\mathrm{LH}$ pulse frequency for only 10-20 days but continues to promote testicular growth over several months. Different signals and different target organs seem to be responsible for these short- and long-term responses. Short-term dietary treatments lead to changes in blood concentrations of glucose, fatty acids, insulin and leptin, and concentrations of glucose, insulin, leptin and some amino acids in cerebrospinal fluid. It seems unlikely that amino acids affect GnRH-LH secretion directly in sheep. Intracerebroventricular infusions of insulin specifically increase LH pulse frequency, but intravenous, intra-abomasal or intracerebroventricular infusions of glucose have no effect, despite their effects on cerebrospinal fluid insulin concentrations. The addition of fatty acids to the diet also increases LH pulse frequency, but does not affect the concentrations of insulin or leptin in the cerebrospinal fluid. It appears that acute responses to changes in nutrition involve a range of alternative pathways, possibly including interactions among insulin, leptin and energy substrates. Effects of long-term dietary treatments on testicular size are only partly dependent on the GnRH-LH system (that is, on brain control) and so must also depend on other, as yet unknown, pathways. Concepts of 'metabolic sensing and integration' are being developed from the basis of existing knowledge of the central control of appetite and reproduction.
\end{abstract}

\section{Introduction}

In male sheep, reproductive activity is affected by a range of external factors, including socio-sexual cues, photoperiod and nutrition (Fig. 1). In sexually mature Merino rams, nutrition is arguably the most powerful of these factors and the responses to it can be divided into short-term effects that act mainly on the neuroendocrine system controlling testicular activity (Martin et al., 1994a) and long-term effects that act on testicular growth and sperm production (Oldham et al., 1978). This review will address the nature of the link between nutrition and reproductive function at both testicular and brain levels, demonstrating the complexity of the metabolic inputs and illustrating how far we have been drawn from hypotheses based on single metabolites. The review will conclude with an overview of our working hypothesis of the regulatory mechanism. The main focus will be on our primary experimental model, the mature male sheep, but arguments will be extended to studies in female sheep and other species in which the nutrition-reproduction link has been investigated.

*This review is based on a symposium talk given at the meeting of the Society for the Study of Fertility held at the University of Aberystwyth in July 1999. tCorrespondence.

\section{Short-term effect of nutrition on gonadotrophin secretion: brain}

\section{The reproductive axis}

The most fundamental driver of reproductive function is a group of neuroendocrine cells in the preoptic-hypothalamic continuum that synthesizes GnRH. These cells secrete discrete pulses of GnRH into the portal blood system leading to the anterior pituitary gland where they elicit pulses of LH and a relatively continuous stream of FSH. Both $\mathrm{LH}$ and FSH are involved in the regulation of the production of both spermatozoa and hormones by the testis. The frequency of GnRH pulses, and consequently LH pulses, is the code used by the nervous system to control testicular function. Direct measurement of the activity of GnRH cells is difficult, but usually unnecessary because LH pulses are easily detected in peripheral blood and their frequency can be used as a bioassay of GnRH cellular activity (Thiéry and Martin, 1991).

The network of neurones that controls GnRH secretion is not yet defined, but it is thought to be the final common pathway via which many factors influence gonadal activity, including metabolic status (for reviews, see Cameron et al., 1993; Martin et al., 1994b). In fact, energy deficits, caused by low intake or by excessive expenditure (for example, 


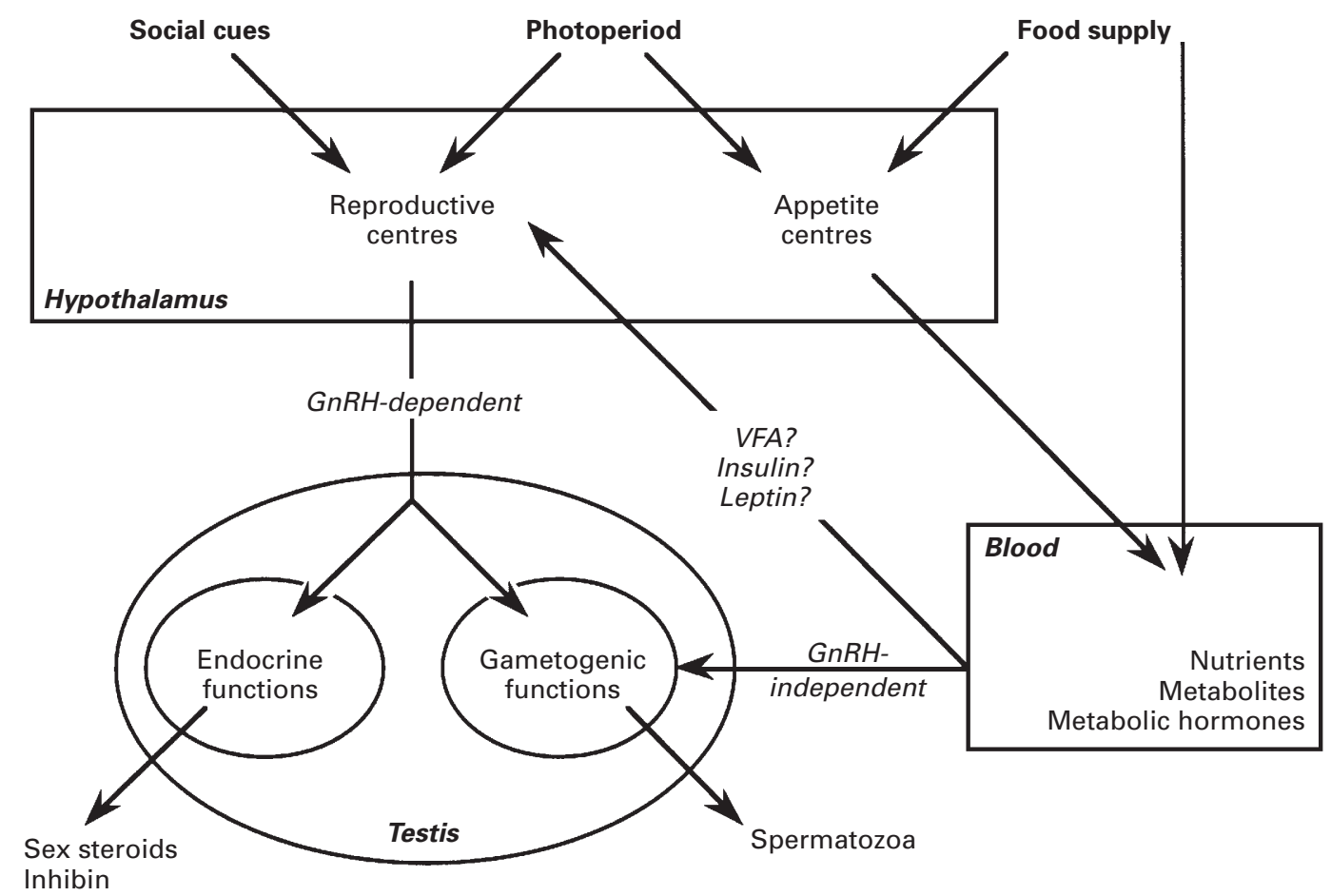

Fig. 1. Scheme describing interactions between photoperiod, social and nutritional cues in the control of hypothalamo-pituitary-testicular axis in male Merino sheep (adapted from Martin et al., 1994b).

exercise), decrease gonadotrophin secretion in both sexes of many species, including humans, and restoration of normal feeding patterns reverses the gonadotrophin deficit (Vigersky, 1984; Stewart, 1992; Dong et al., 1994; Cameron, 1996). In mature male sheep, similar effects have been observed, including the reduction of LH pulse frequency after reduction of feed intake (Martin and Walkden-Brown, 1995). However, our model is not based on fasting or on puberty but on switching the mature Merino ram from a diet that maintains constant bodyweight (a 'maintenance $\operatorname{diet}^{\prime}$ ) to one providing approximately twice the maintenance requirement. Thus, the energy and protein intake are increased so as to promote weight gain within 1 month. This acute change induces an increase in $\mathrm{GnRH}$ and LH pulse frequencies, and FSH secretion, within a few days (Martin et al., 1994c). A high plane of nutrition can be imposed acutely without digestive complications by supplementing the maintenance diet with legume grain, which adds large amounts of digestible protein and energy. Typically, lupins (Lupinus angustifolius) or cowpeas (Vigna unguiculata) are used (Blache et al., 1996).

\section{Concentrations of nutrients and hormones in blood and cerebrospinal fluid}

Acutely increasing the plane of nutrition induces changes in the concentrations of nutrients and hormones in both the blood stream and cerebrospinal fluid (CSF). The changes in CSF concentrations may reflect changes in the availability of these substances to brain tissues that regulate the reproductive axis (Table 1 ). Ten days of high food intake leads to increases in the concentrations of arginine, phenylalanine, proline, tyrosine, methionine and phosphoserine in both plasma and CSF, but aspartate and serine concentrations increase only in plasma. Plasma concentrations of volatile fatty acids and linoleic acid also increase with this feeding regimen. Among the metabolic homeostatic factors, plasma concentrations of insulin, leptin, glucose and insulinlike growth factor I (IGF-I) increase but, in CSF, only the concentrations of insulin, leptin and glucose are affected. High levels of nutrition do not affect the concentrations of tri-iodothyronine, thyroxine or cortisol in plasma or CSF. These observations indicate that insulin, glucose, volatile fatty acids and certain amino acids are among the humoral metabolic signals that modulate $\mathrm{GnRH}$ and gonadotrophin secretion.

\section{Nutrients as signals?}

Among the nutrients affected by an increase in food intake in sheep, the volatile fatty acids are of particular interest because they are produced in large amounts by the normal processes of ruminant digestion. Exogenous fatty acids were added to the low diet (acetate, propionate and oils to an equivalent level as supplied by a supplement of lupin grain; for composition of the low diet see Table 1) to test whether volatile fatty acids are involved in the control of LH secretion in male sheep. This treatment increased LH pulse frequency, but the response was smaller than with a lupin supplement (Boukhliq and Martin, 1997), indicating that fatty acids are, 
Table 1. Changes in concentrations of nutrients and hormones in plasma and cerebrospinal fluid in mature rams 5 days after a change of diet from a low energy and protein diet that maintains constant body mass (9 MJ per day and $69 \mathrm{~g}$ crude protein per day) to a high protein and energy diet (21 MJ per day and $380 \mathrm{~g}$ crude protein per day)

\begin{tabular}{|c|c|c|c|c|}
\hline & & Plasma & CSF & References \\
\hline Glucose & & $\uparrow$ & $\uparrow$ & Boukhliq et al., 1996 \\
\hline \multirow{10}{*}{ Amino acids } & Arginine & $\uparrow$ & $\uparrow$ & Miller et al., 1998 \\
\hline & Methionine & $\uparrow$ & $\uparrow$ & Miller et al., 1998 \\
\hline & Phenylalanine & $\uparrow$ & $\uparrow$ & Miller et al., 1998 \\
\hline & Phosphoserine & $\uparrow$ & $\uparrow$ & Miller et al., 1998 \\
\hline & Proline & $\uparrow$ & $\uparrow$ & Miller et al., 1998 \\
\hline & Tyrosine & $\uparrow$ & $\uparrow$ & Miller et al., 1998 \\
\hline & Aspartate & $\uparrow$ & $=$ & Miller et al., 1998 \\
\hline & Serine & $\uparrow$ & $=$ & Miller et al., 1998 \\
\hline & $\gamma$-Aminobutyric acid & $=$ & $\uparrow$ & Miller et al., 1998 \\
\hline & Isoleucine & $=$ & $\uparrow$ & Miller et al., 1998 \\
\hline \multirow[t]{5}{*}{ Fatty acids } & Propionate & $\uparrow$ & $?$ & Harman, 1991 \\
\hline & Acetate & $\uparrow$ & $?$ & Harman, 1991 \\
\hline & Butyrate & $\uparrow$ & $?$ & Harman, 1991 \\
\hline & Linoleic acid & $\uparrow$ & $?$ & Miller et al., 1998 \\
\hline & Oleic acid & $=$ & $\uparrow$ & Miller et al., 1998 \\
\hline \multirow[t]{7}{*}{ Hormones } & Insulin & $\uparrow$ & $\uparrow$ & Boukhliq et al., 1996 \\
\hline & IGF-I & $\uparrow$ & $=$ & Miller et al., 1998 \\
\hline & Growth hormone & $\downarrow$ & $?$ & Blache et al., 1996 \\
\hline & Tri-iodothyronine & $=$ & $=$ & Miller et al., 1998 \\
\hline & Thyroxine & $=$ & $=$ & Miller et al., 1998 \\
\hline & Cortisol & $=$ & $=$ & Miller et al., 1998 \\
\hline & Leptin & $\uparrow$ & $\uparrow$ & Blache et al., 2000 \\
\hline
\end{tabular}

The change of diet induced an increase in LH pulse frequency but no change in body mass within the 5 days. The rams were fed the low energy diet for at least 2 weeks before the change of diet. Their body condition scores are generally between 1 and 2 . CSF: cerebrospinal fluid.

at most, only part of the signal that affects gonadotrophin secretion. It is not clear whether direct infusion of fatty acids into the CSF would also stimulate the gonadotrophin secretion.

Most of the amino acids that are affected by changes in diet do not seem to be important because, in female sheep, intravenous infusion of precursors of neurotransmitters or of large neutral amino acids does not affect LH secretion (Downing et al., 1995, 1996, 1997). It is difficult to see why normal aspects of brain function would depend on day-today fluctuations in the availability of a single amino acid. This is a distinctly different scenario to the pathological situation in which the animal is chronically deficient in an essential amino acid.

Glucose has long been a favoured candidate as the metabolic link between nutrition and reproduction (Schillo, 1992). In female sheep, insulin-induced hypoglycaemia inhibits LH secretion and administration of glucose reverses the effect (Clarke et al., 1990; Funston et al., 1995) and stimulates LH in growth-restricted wethers (Branum et al., 1997). In addition, in rats and lambs, 2-dexoxy-glucose, a competitive inhibitor of glycolysis, decreases LH pulse frequency to values typically seen in undernourished animals (Bucholtz et al., 1996; Nagatani et al., 1996). However, in several experiments with mature male sheep fed a low energy diet, intra-abomasal and intravenous infusions of glucose did not stimulate pulsatile LH secretion (Miller et al., 1995; Boukhliq et al., 1996; Boukhliq and Martin, 1997). These studies appear contradictory, but the mechanisms that decrease GnRH activity in the virtual absence of glucose may differ from those activated by a 'normal' change in food intake. The specificity of responses to insulin or 2-dexoxyglucose is questionable because glucose is the preferred substrate for all nervous tissue, not only those involved in the control of GnRH secretion. Therefore, we contend that glucose does not act independently as a nutritional signal from peripheral tissues to the brain.

Glucose may be involved in interactions with other metabolic factors. Glucose transporters 1, 3, 4 and 5 are present in the rodent brain (for review, see Gould, 1997). Among them, GLUT-4, an insulin-regulatable transporter in peripheral tissues (Zornano and Camps, 1997), is the most interesting because it is affected by the level of nutrition in skeletal muscle and adipose tissue of mice (Ezaki 1997). In rats, GLUT-4 is present in ependymal cells lining the cerebral ventricles, and in the arcuate and the ventromedial nuclei of the hypothalamus (Kobayashi et al., 1996; Leloup et al., 1996). This finding would be compatible with an insulin-glucose interaction in the control of GnRH secretion if GLUT-4 was either present in the GnRH neurones themselves or in neurones controlling $\mathrm{GnRH}$ secretion. If this were the case, insulin could activate $\mathrm{GnRH}$ secretion by stimulating 


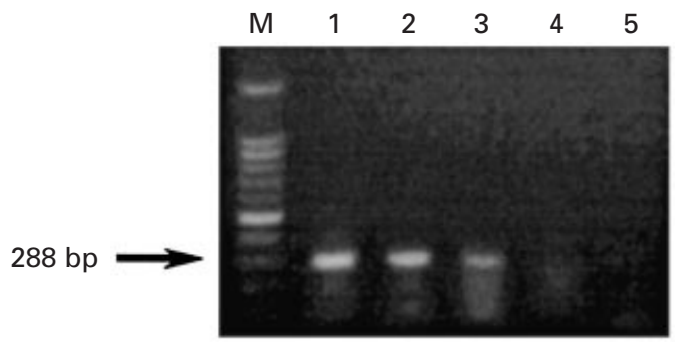

Fig. 2. RT-PCR for insulin receptor using total RNA isolated from pituitary gland (lane 1), medio-basal hypothalamus (lane 2) and liver (lane 3) of male sheep. Lane M: molecular mass markers; lane 4: control 1, liver without primers; lane 5: control 2, primers only. Total RNA was isolated using RNazol B (Geneworks, Adelaide) followed by RT-PCR. The primers were designed according to conserved regions of DNA identified by aligning the insulin receptor genes from humans and mice. The amplified fragment (288 bp) from the ovine insulin receptor gene is homologous to human $(92 \%)$, mouse $(92 \%)$ and rat $(88 \%)$ insulin receptor within exon 2 (M. A. Blackberry, P. V. Vercoe and D. Blanche, unpublished).

glucose uptake by the neurones. However, the cerebral location of GLUT- 4 needs to be verified in sheep because Abe et al. (1997) could not find its mRNA in the brain of cattle, another ruminant.

\section{Metabolic hormones as signals?}

Insulin. Male sheep fed on a high plane of nutrition have high concentrations of insulin in both plasma and CSF (Table $1)$. This observation led us to infuse a low dose of insulin $\left(0.6 \mathrm{ng} \mathrm{h}^{-1}\right)$ into the third ventricle of rams fed on a low diet. Animals were infused for $12 \mathrm{~h}$ per day for 4 days, a protocol that was designed to replicate the daily pattern in insulin concentration observed in CSF in well-fed animals. This treatment increased LH pulse frequency to values that were similar to those seen in well-fed rams. The response to intracerebroventricular (i.c.v.) insulin was not enhanced by simultaneous i.c.v. infusion of glucose (Miller et al., 1995). Therefore, we proposed that insulin, passing from pancreas to blood to CSF to hypothalamic tissue, is a major metabolic modulator of GnRH secretion. This hypothesis is supported by the presence of mRNA for ovine insulin receptor in the hypothalamic tissue of rams (Fig. 2). However, some more recent studies have challenged this simple hypothesis, particularly in the light of the finding that changes in CSF concentrations of insulin are not always correlated with changes in LH pulse frequency: (i) the addition of volatile fatty acids to the diet moderately increases LH pulse frequency but is not accompanied by an increase in CSF insulin; and (ii) intravenous infusion of glucose does not affect LH pulse frequency but greatly increases the CSF concentration of insulin (Fig. 3).

These findings led us to critically re-examine the role, and even the relevance, of CSF concentrations of insulin (or any other substance): first, a mechanism that may become saturated at high concentrations of insulin regulates the passage of insulin from blood to CSF through the brain-blood barrier (King and Johnson, 1985); second, the concentration of insulin in CSF might reflect the passage of this hormone from the plasma but might not reflect the amounts that reach targets in the neural tissue; third, CSF is a complex mixture of hormones and metabolites that are derived simultaneously from the blood stream and from brain tissue (as overflow from local production). In fact, the demonstration of mRNA encoding insulin in the brain of rabbits (Schechter et al., 1988, 1994) provides evidence for the local production of insulin. Moreover, the concentration of insulin in brain tissue varies independently of plasma concentrations in rats that are made hyper- or hypoinsulinaemic by natural, genetic or artificial means (for review, see Plata-Salamán, 1991). Therefore, it is possible that the simple pathway, in which pancreatic insulin passes via the CSF to neural tissue, is not the route through which nutritional signals stimulate GnRH neurones and might not be relevant to the responses to i.c.v. infusions of the hormone. An alternative is that the sensitivity of the neural tissue to insulin varies with changes in diet, so that insulin concentrations would not necessarily need to fluctuate. This mechanism might involve changes in insulin receptor expression or the intracellular signalling mechanisms.

A further alternative is that high energy and protein diets, or feeding with volatile fatty acids (in ruminants), somehow stimulate the production of insulin in brain tissue, leading to a localized increase in tissue concentrations that stimulates the GnRH pulse generator. In treatments that do not affect plasma insulin concentrations, the flow from local production alone into CSF may be too small for any change in concentration to be detectable (CSF insulin concentrations are always low and difficult to assay). The pathway by which dietary changes stimulate insulin synthesis in brain tissue may involve other metabolites or hormones influenced by nutrition, or perhaps peripheral nervous inputs from the liver or the gut.

Insulin-like growth factors. The presence of IGF-I and its receptor in the rat hypothalamus (Bohannon et al., 1988; Schechter et al., 1994) has raised the possibility that IGF-I plays a role similar to that of insulin as a link between nutrition and gonadotrophin secretion. The fact that insulin and IGF-I are recognized by each other's receptors (Zapf et al., 1978; Gammeltoft et al., 1984) opens two possibilities: insulin may bind to IGF-I receptors and elicit similar responses to IGF-I (Rechler and Nissley, 1986), or IGF-I may bind to its own receptors or act on insulin receptors (Zapf et al., 1978; Gammeltoft et al., 1984). In juvenile and peripubertal female rats, i.c.v. injections of small doses of IGF-I induced GnRH and LH release (Hiney et al., 1996). In castrated rams, peripheral administration of physiological doses of IGF-I can stimulate LH secretion (Adam et al., 1998). In mature rams, peripheral concentrations of IGF-I are affected by diet, but CSF concentrations are not (Miller et al., 1998), and preliminary studies indicate that IGF-I infusion into the third ventricle does not affect LH pulse frequency. Therefore, it seems unlikely, at least in mature males, that IGF-I acts as a central mediator of nutritional status. However, insulin may act on IGF-I receptors, the presence of which still needs to be confirmed in ovine brain tissue. 


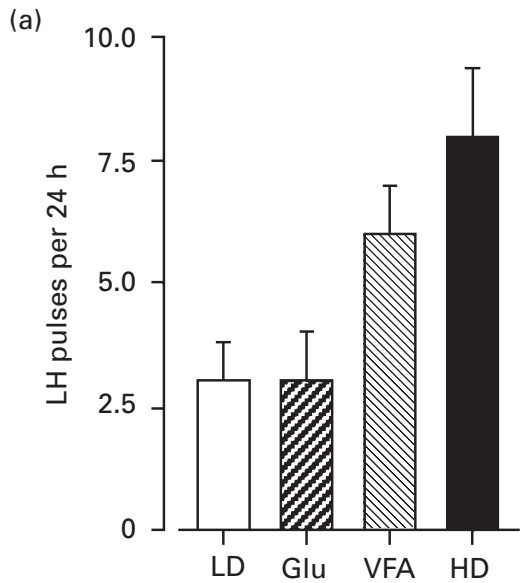

(b)

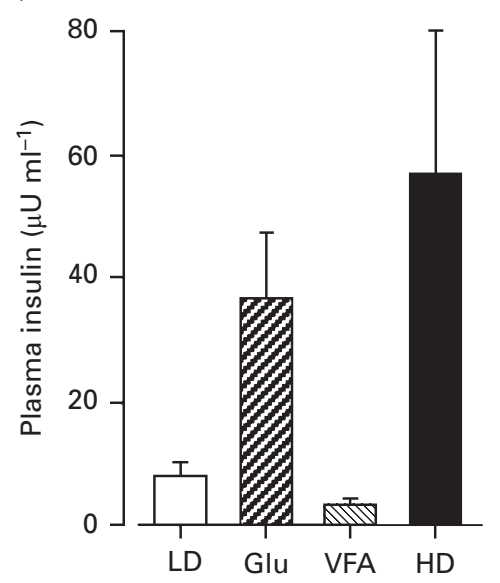

(d)

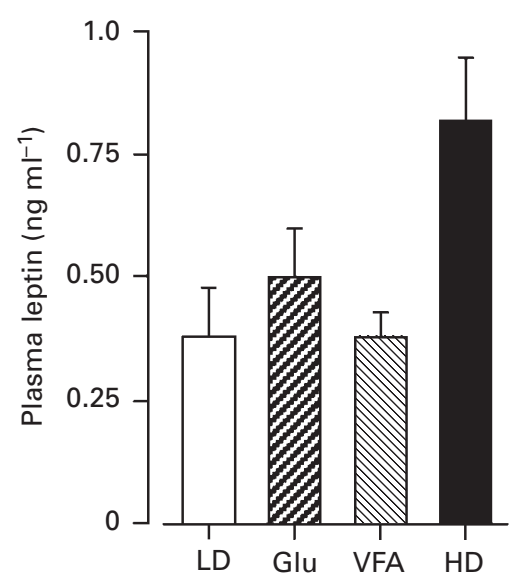

(c)

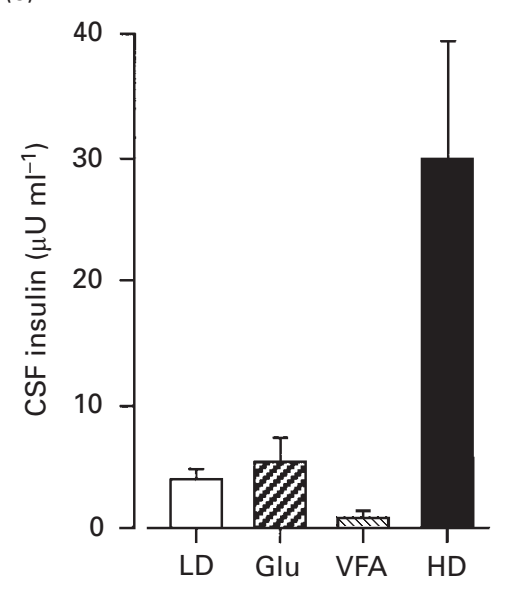

(e)

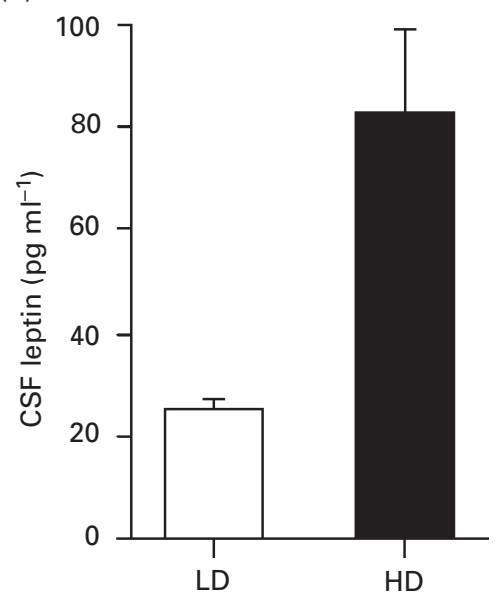

Fig. 3. LH pulse frequency (a), and concentrations of insulin in plasma (b), insulin in cerebrospinal fluid (CSF) (c), leptin in plasma (d) and leptin in CSF (e) in rams fed a low energy and protein diet $(\square, L D, 9$ MJ and $69 \mathrm{~g}$ of crude protein per day), fed the same diet supplemented with volatile fatty acids $(\mathbb{\nabla}, V F A)$, fed the same diet and infused intravenously with glucose $(\boldsymbol{Z}, \mathrm{Glu})$, or fed a high energy and protein diet $(\boldsymbol{\square}, \mathrm{HD})$. All the treatments were given for 5 days. (Data from Chagas et al., 1997, 1999a,b.) 
Leptin - the role of adipose tissue. The secretion of the metabolic hormones discussed above is mainly influenced by acute changes in nutrition. However, if we consider the energy reserves and energy balance of the body as a whole over the long term, as the reproductive centres of the brain arguably would, we would expect responses to the level of labile energy reserves as well as to changes in current dietary status (Lindsay et al., 1993). Adipose tissue is the major site of energy storage and, ever since the 'lipostatic' theory was proposed (Kennedy, 1953), there has been a search for a signal connecting these stores to the brain centres that control food intake. The discovery of leptin and its receptor, and the proposal that this adipose hormone acts as a longterm indicator of energetic balance and reserves, interested reproductive physiologists who went on to demonstrate that leptin injections increased gonadotrophin secretion and ovarian and testicular activity in leptin-deficient and obese mice (Barash et al., 1996; Chehab et al., 1996; Mounzih et al., 1997). It was also found that, in normal female rats and mice, and male monkeys, the inhibition of LH secretion during fasting could be overcome by leptin treatment (Ahima et al., 1996; Carro et al., 1997; Weigle et al., 1997; Finn et al., 1998; Nagatani et al., 1998).

In sheep, the leptin gene, protein and receptor gene have been identified (Dyer et al., 1997a,b). As in other species, leptin receptors were found in the choroid plexus and the hypothalamus of both sexes (Dyer et al., 1997b; Williams et al., 1999), and the expression of receptor mRNA in hypothalamic and pituitary tissue from ovariectomized ewes was found to be greater in underfed than in well-fed animals (Dyer et al., 1997b). Moreover, plasma concentrations of leptin, measured using a commercial kit (Multi-species Leptin RIA kit, Linco Research, St Louis, MO), seemed to vary with food intake and to be correlated with body fatness in mature ovariectomized ewes (Chilliard et al., 1998a, 1998b). In addition, evidence was found that leptin is taken up by the brain in intact female sheep (McFarlane et al., 1999).

We have developed a double-antibody radioimmunoassay using a preparation of recombinant bovine leptin with a structure that differs by only two conservative amino acids with the published sequence for ovine leptin (Blache et al., 2000). This preparation, which has been termed 'b/o-leptin', reduces feed intake when infused i.c.v. into mature rams (Celi et al., 1999). The method has been described in detail by Blache et al. (2000) but, briefly, b/o-leptin was used to raise an antibody in a male emu and to prepare standards and iodinated tracer (chloramine-T method). The limit of detection is $100 \mathrm{pg} \mathrm{ml}^{-1}$ in plasma and $25 \mathrm{pg} \mathrm{ml}^{-1}$ in CSF. The following have been demonstrated: (1) there is parallelism for plasma from sheep, cattle, goats and horses; (2) that, in sheep, leptin is correlated to backfat thickness in intact females and wethers; (3) that plasma leptin concentrations are higher in females than in castrated males with the same body weight; (4) that leptin is not secreted in a pulsatile manner in intact male sheep; and (5) that plasma leptin does not exhibit a circadian rhythm, an observation confirmed using an ELISA based on the same recombinant bovine leptin (Kauter and McFarlane, 1999). Plasma and CSF leptin concentrations are higher in rams fed high diet (see Table 1) than in underfed rams, and this difference correlates with LH pulse frequencies (Fig. 3). Most of these results agree with those from studies with humans and rodents (for review, see Casanueva and Dieguez, 1999).

Are these observations consistent with a role for leptin in the link between nutrition and reproduction in the mature male sheep? The circumstantial evidence (Fig. 3) is encouraging, but i.c.v. infusion of recombinant human leptin does not affect LH secretion in ovariectomized ewes (Henry et al., 1999). The use of human leptin in this study does not necessarily explain this result as the same preparation reduces feed intake in ovariectomized ewes. It is feasible that ovariectomized ewes, with their inherently high LH pulse frequency, are not the best model for detecting increases in frequency in response to leptin. However, with testis-intact, mature rams fed ad libitum, preliminary data indicate that i.c.v. infusion of leptin into the third ventricle decreases $\mathrm{LH}$ pulse frequency within 5 days. This inhibition is apparently a side-effect of the decreased feed intake caused by the leptin infusion, as demonstrated with pair-fed controls (Celi et al., 1999).

Moreover, leptin seems to be, at best, only one component of the metabolic regulation of GnRH-LH secretion; as is the case with insulin, plasma leptin concentrations are not increased by a dietary supplement of volatile fatty acids that increases LH pulse frequency (Fig. 3). Overall, observations to date indicate that the nutrition-induced changes in leptin and its receptor in ewes are simply correlations between reproductive events and responses to nutrition, rather than a reflection of cause and effect. At this stage, comparison of the available reports is confounded by too many uncontrolled variables, including sex, stage of sexual development, animal condition and dietary treatments. For example, leptin may play a role in the long-term, but not the short-term, regulation of the reproductive axis, as has been suggested in humans and rats (Casanueva and Dieguez, 1999). This is consistent with the 3 week delay between change of diet and change in the expression of ovine leptin receptor in the hypothalamus (Dyer et al., 1997b). Our studies in males are all based on short-term responses, elicited within a few days. The sexes may differ fundamentally in the mechanisms that they use to link energy balance to reproduction, if only because they differ so much in their metabolic commitments to the reproductive process, to sperm production versus pregnancy and lactation. Moreover, the role of leptin may differ among species and breeds, as a result of adaptation to different patterns of food availability. A permissive role for leptin in the regulation of the reproductive axis may not be as crucial in sheep as it seems to be in humans or rodents (Casanueva and Dieguez, 1999), perhaps reflecting fundamental differences between monogastrics and ruminants. In summary, it is highly likely that leptin does not act alone, but is a member of a cohort of factors, humoral and perhaps neural, that influences the activity of the GnRH pulse generator.

\section{Brain mechanisms: another level of complexity}

The multiplicity of neural inputs to the GnRH pulsegenerating system can be added to the multiplicity of 
metabolic inputs from the gut to the brain. As well as signals from neurones sensitive to leptin or insulin, there is a wide range of neuropeptides that influence food intake or $\mathrm{GnRH}$ neuronal activity, or both, and it would be impossible to review them here. However, studies with rodents and monkeys have shown that pro-opiomelanocortin and neuropeptide Y (NPY) are coexpressed with the leptin receptor (Cunningham et al., 1999) and that cocaine- and amphetamine-regulated-transcript peptide may be involved in the stimulation of GnRH pulse generator by leptin in rat GnRH cell culture (Lebrethon et al., 2000). The list of potential inputs has been increased by the discovery of the orexins (or hypocretins), two small neuropeptides (Sakurai et al., 1998). There is already evidence indicating that orexins are involved in the link between reproductive function and nutrition, at least in rats. First, immunohistochemical studies have shown that the distribution of orexin fibres overlaps with that of the GnRH neuronal system in the septo-preoptic area and arcuate nucleus-median eminence (Peyron et al., 1998). Second, i.c.v. infusion of orexin A or B rapidly stimulates LH secretion in steroid-pretreated, ovariectomized rats, but inhibits LH release in ovariectomized rats that have not been primed with steroids, indicating a major interaction between these inputs into the control of tonic LH secretion (Pu et al., 1998; Tamura et al., 1999). Third, terminals containing orexin have been found in the vicinity of neurones containing both NPY and leptin receptors (Horvath et al., 1999). Central NPY is known to be involved in the link between nutrition and reproduction and has been implicated in the control of LH pulse frequency in ovariectomized female sheep (McShane et al., 1992, 1993; Barker-Gibb et al., 1995).

A population of orexin neurones seems to be activated by hypoglycaemia (Moriguchi et al., 1999) and, in rats, orexin neurones can be stimulated by a single injection of insulin, but only under hypoglycaemic and not hyperglycaemic conditions (Griffond et al., 1999), implying direct interactions with insulin and glucose. Overall, these developments indicate that it is necessary to determine where orexin is located in the sheep brain and test for effects of nutritional status on the production of the neuropeptide and its receptors. As mentioned above for other central pathways, the peripheral signals to the orexin pathway need to be identified.

In the first part of this review, the ways have been considered in which metabolic factors, such as volatile fatty acids, glucose and insulin, might be involved in the short-term effects of nutrition on the higher reproductive centres of male sheep. A role for insulin, possibly centrally synthesized, appears necessary if all the above observations are to be accommodated. Leptin alone cannot be the essential link but an interaction between insulin and leptin may play a permissive role, as has been suggested for the onset of puberty in rodents, humans and sheep (Foster et al., 1995; Casanueva and Dieguez, 1999). Thus, our current search for the central pathways linking nutrition to reproduction is focused on the roles of central insulin and the newly discovered orexins. Because the orexins, NPY, leptin, sex steroids and insulin do not seem to act independently of each other, part of the challenge will be to understand the interactions between them.

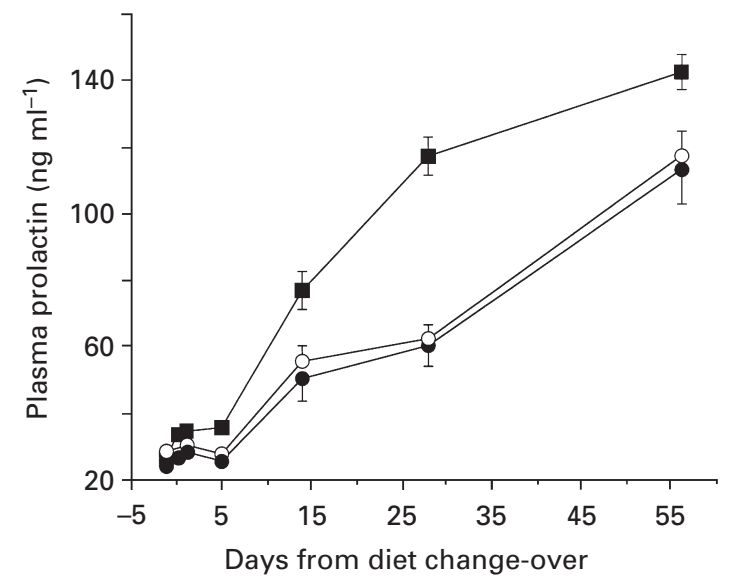

Fig. 4. Effect of diet on plasma concentrations of prolactin (NIADDK-oPRL-I-2) in mature rams fed a maintenance diet $(\bigcirc)$, a half-maintenance diet () or the maintenance diet plus $750 \mathrm{~g}$ lupin grain per day $(\boldsymbol{\square})$. (From the experiment described by Tjondronegoro et al., 1992.)

\section{Long-term effect of nutrition on testicular function}

In rams, the long-term, seasonal changes in testicular size and sperm production that are driven by photoperiod are implemented by long-term changes in GnRH pulse frequency and thus LH and FSH secretion (Lincoln and Short, 1980). Putting rams on a high energy and protein diet also increases GnRH pulse frequency, but the effect fades after 3 weeks of treatment. Despite this fading of the effect, testicular mass and sperm production continue to increase for several months, or at least as long as the diet is offered (Oldham et al., 1978; Ritar et al., 1984; Martin et al., 1987, 1994c). This finding indicates that part of the effect of diet on the testis is independent of the changes in $\mathrm{GnRH}$ pulse frequency. This hypothesis has been tested in two studies with mature Merino rams. First, the endogenous GnRH pulse pattern was overridden by superimposing an exogenous regimen of $\mathrm{GnRH}$ pulses at a higher frequency (similar to that observed in rams acutely fed a supplement), and then adding nutritional treatments. The key observation was that, in underfed rams, a high frequency of exogenous GnRH pulses did not induce testicular growth (Hötzel et al., 1995). The second approach was to actively immunize rams against GnRH and challenge them with changes in nutrition. In this situation, a high level of nutrition did not induce testicular growth but reduced the rate of regression of the testes that was induced by the absence of GnRH. We concluded that both a GnRH-dependent pathway and a $\mathrm{GnRH}$-independent pathway are involved in the regulation of testicular growth by nutrition.

Among the possible GnRH-independent mechanisms are direct effects of changes in nutrient availability on testicular metabolism, and effects of changes in other metabolic endocrine systems (Lindsay et al., 1993). Testicular growth and regression in rams are directly correlated with changes in body weight (Murray et al., 1990) and the secretion of growth hormone, insulin and IGF-I (Blache et al., 1996; Miller 


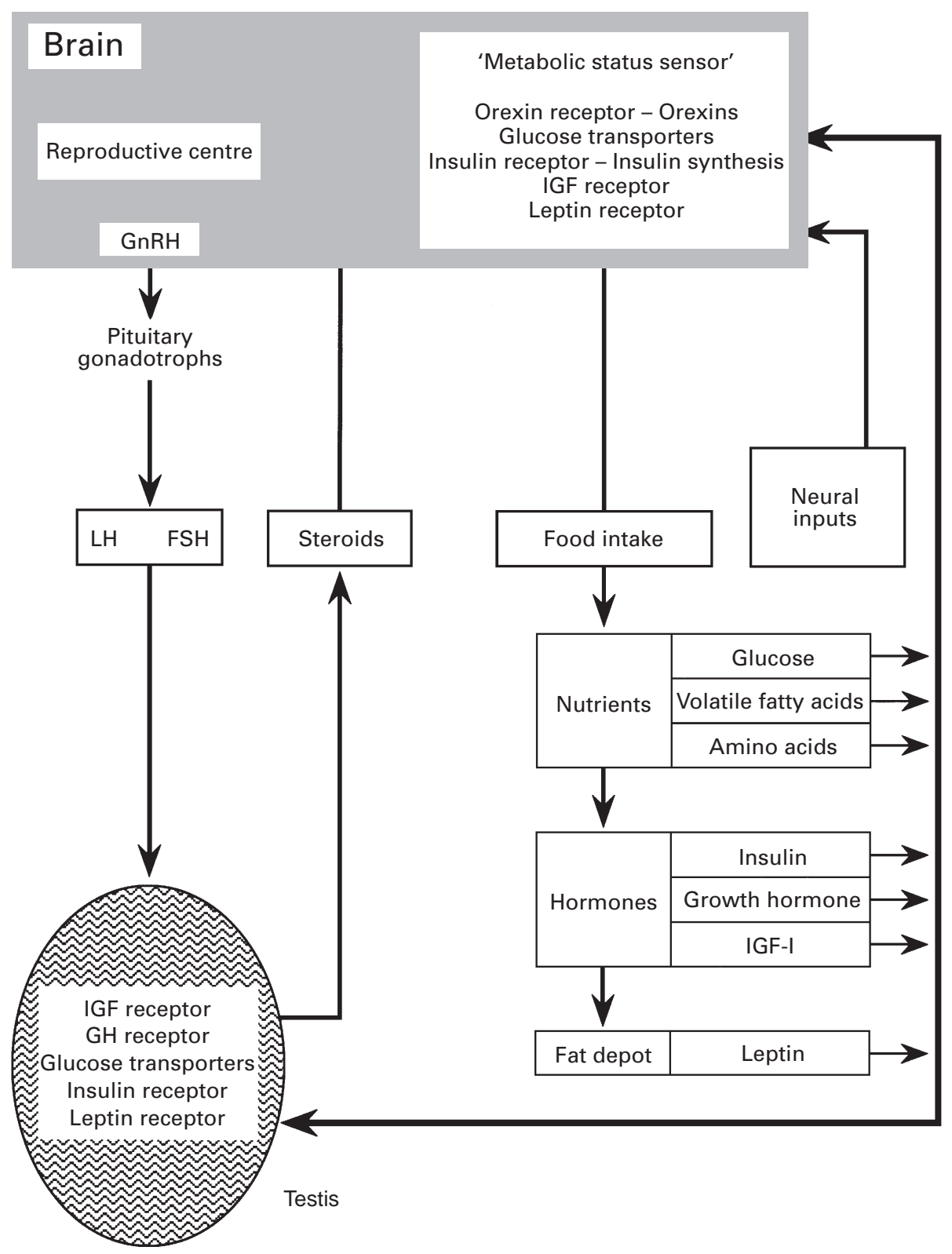

Fig. 5. Summary of the general hypothesis illustrating interactions between a range of metabolic hormones and factors in the control of $\mathrm{GnRH}$ secretion and the postulated 'metabolic status sensor' that is able to integrate the multiple inputs coming from either the periphery or the brain, and also link appetite and reproduction. GH, growth hormone; IGF-I, insulin-like growth factor I.

et al., 1996). The testis contains receptors for both IGF-I and growth hormone, so the somatotrophic axis may mediate the effects of nutrition on the testis, as has been suggested to occur in the ovary (Monget and Martin, 1997). However, in rams immunized against $\mathrm{GnRH}$, in which plasma concentrations of growth hormone and IGF-I are very low, the testicular responses to change in diet are not affected (Martin and Walkden-Brown, 1995). Another alternative is prolactin, which is affected by the nutritional treatments in much the same way as gonadotrophin secretion (Fig. 4) and which has receptors in the ram testis (Jabbour and Lincoln, 1999).
The search for mechanisms by which nutrition influences testicular function may lead to a better understanding of related effects in the brain because the testis and brain are both putative targets for the same nutrients and hormones. Thus, in rats, the testis also contains the glucose transporters GLUT3 and GLUT5 which are not insulin-sensitive (for review, see Gould, 1997). Insulin receptors have been found in the Leydig cell membrane (Abele et al., 1986) and insulin has long been thought to have a role in steroidogenesis in both sexes (Abele and Tremblay, 1985; Poretsky and Kalin, 1987). In addition, the amount of insulin receptor in the testicular cell membrane is apparently increased by pituitary 
LH (Saucier et al., 1983; Abele and Tremblay, 1985). These observations are compatible with a role for insulin in the long-term effect of nutrition. The transient increase in LH secretion induced by a dietary supplement may well increase the sensitivity of the testicular tissues to insulin and thus initiate persistent testicular growth. This hypothesis needs to be investigated in our model. Similarly, receptor mRNAs for the adipose hormone, leptin, have been localized in the rat testis (Hoggard et al., 1997) and leptin has been shown to inhibit testosterone secretion from adult rat testis in vitro (Tena-Sempere et al., 1999). Thus, as with the work focussing on the brain, an understanding of the interactions between the various humoral systems acting on the testis will be necessary for the study of the long-term effects of nutrition.

\section{Conclusion: concepts derived from the regulation of energy balance}

This review has concentrated on reproductive responses in relation to the generalized concept of 'level of nutrition'. In real terms, animals are probably sensitive to changes in energy balance: the difference between disposable energy and expended energy. The disposable energy comprises both daily food intake and labile stores. In an ideal situation, energy output equals energy input so that 'body condition' remains more or less constant. Short-term modifications of this equilibrium are buffered because the body has sufficient stores (of fat, for example) to counter any abrupt changes in food intake or energy expenditure. However, long-term divergences from this equilibrium that result in changes in body condition constitute an energetic challenge that will cause animals to vary their ability to reproduce.

Large organisms have developed a variety of pathways to ensure that the body will be provided with at least the minimum energy required for survival (for review, see Frayn, 1996). Consequently, short-term and long-term decreases or increases in food intake will affect their metabolism in different ways. The effects of short-term starvation (for example, overnight) on metabolism are very different to those of long-term starvation, in much the same way that the effects of long-term intensive exercise differ from those of bursts of muscular activity. This complexity means that understanding the amount of energy available at a given time is a delicate task for the researcher, although it is clear that the components of the reproductive system (brain, pituitary gland and gonads) are capable of making such an assessment and providing an appropriate response.

Our understanding of the relationship between nutrition and reproduction has advanced well beyond the 'glucose hypothesis', and probably the 'leptin hypothesis' too, but we are still far from being able to describe an integrative system that can read subtle changes in energy balance. Future research in this area needs to abandon the simplistic concept that the reproductive axis is controlled by the 'level of nutrition' and move towards alternative concepts, such as a 'metabolic status sensor' (Fig. 5). This 'sensor' would need to orchestrate all of the processes that regulate food intake, energy expenditure and reproduction. Not surprisingly, research on the neurobiology of appetite control has taken a similar path (Campfield, 1997). The next challenge will be to tackle the integrative role of the hypothetical 'metabolic status sensor', which will require consideration of the entire range of inputs into it. The list of signals so far described is clearly too short and more signals will be added, each of them acting as either a 'permissive' or 'repressive' signal according to the levels of all the other inputs into the 'sensor-integrator'.

The location of this sensor is almost certainly the hypothalamus, but the wiring of the sensor itself, and the wiring from the sensor to the effectors (appetite and $\mathrm{GnRH}$ neurones) is not clear. A large number of neurotransmitters are involved in the control of both food intake and GnRH neuronal activity (for reviews, see Kalra and Kalra, 1994; Kalra et al., 1999). However, 'hard-wired' transmission (for example, orexin-sensitive neurones), or one-to-one transmission, which includes classical synapses, gap junctions and membrane juxtapositions, may not provide an appropriate model of the fine structure of the 'sensor-integrator'. More recent concepts, such as volume transmission or one-to-many transmission that have emerged from studies of neurotransmission (Zoli et al., 1999a,b), including paracrine and endocrine-like transmissions in the extracellular cerebral space and CSF, may prove more useful in describing the integrative role of a metabolic 'sensor-integrator'.

The authors thank Ross Tellam (CSIRO Tropical Agriculture, Queensland, Australia) for the production of recombinant bovine hexaHis-leptin. The animal experiments described here would not have been possible without help willingly provided by everyone in the Animal Science Group. This work was supported by the National Health and Medical Research Council (grant number 981672) and the Australian Research Council. Lucia Chagas was supported by the Brazilian Research Council (CNPq).

\section{References}

Abe H, Morimatsu M, Nikami H, Miyashige T and Saito M (1997) Molecular cloning and mRNA expression of the bovine insulin-responsive glucose transporter (GLUT4) Journal of Animal Science 75 182-188

Abele V and Tremblay RR (1985) Hormonal steroids indirectly influence insulin binding in rat testis Journal of Receptor Research 5 219-230

Abele V, Pelletier G and Tremblay RR (1986) Radioautographic localization and regulation of the insulin receptors in rat testis Journal of Receptor Research 6 461-473

Adam CL, Findlay PA and Moore AH (1998) Effects of insulin-like growth factor 1 on luteinizing hormone secretion in sheep Animal Reproduction Science 50 45-56

Ahima RS, Prabakaran D, Mantzoros C, Qu DQ, Lowell B, Maratosflier E and Flier JS (1996) Role of leptin in the neuroendocrine response to fasting Nature 382 250-252

Barash IA, Cheung CC, Weigle DS, Ren HP, Kabigting EB, Kuijper JL, Clifton DK and Steiner RA (1996) Leptin is a metabolic signal to the reproductive system Endocrinology 137 3144-3147

Barker-Gibb ML, Scott CJ, Boublik JH and Clarke IJ (1995) The role of neuropeptide Y (NPY) in the control of LH secretion in the ewe with respect to season NPY receptor subtype and the site of action in the hypothalamus Journal of Endocrinology 147 565-579

Blache D, Miller DW, Milton JTB and Martin GB (1996) The secretion of gonadotrophins insulin and insulin-like growth factor I by Merino rams supplemented with different legumes seeds Australian Journal of Agricultural Research 47 843-852

Blache D, Tellam R, Chagas LM, Blackberry MA, Vercoe PV and Martin GB (2000) Level of nutrition affects leptin concentrations in plasma and cerebrospinal fluid in sheep Journal of Endocrinology 165 625-637 
Bohannon NJ, Corp ES, Wilcox BJ, Figlewicz DP, Dorsa DM and Baskin DG (1988) Localization of binding sites for insulin-like growth factor I, IGF-I, in the rat brain by quantitative autoradiography Brain Research 444 205-213

Boukhliq R and Martin GB (1997) Administration of fatty acids and gonadotrophin secretion in the mature ram Animal Reproduction Science $\mathbf{4 9}$ 143-159

Boukhliq R, Miller DW and Martin GB (1996) Relationships between the nutritional stimulation of gonadotrophin secretion and peripheral cerebrospinal fluid (CSF) concentrations of glucose and insulin in rams Animal Reproduction Science 41 201-204

Branum JC, Kline RS and Whisnant CS (1997) The effects of neurotransmitter antagonists and glucose on luteinizing hormone secretion in growthrestricted wethers Animal Reproduction Science 45 263-272

Bucholtz DC, Vidwans NM, Herbosa CG, Schillo KK and Foster DL (1996) Metabolic interfaces between growth and reproduction 5. Pulsatile luteinizing hormone secretion is dependent on glucose availability Endocrinology 137 601-607

Cameron JL (1996) Regulation of reproductive hormone secretion in primates by short-term changes in nutrition Reviews of Reproduction 1117-126

Cameron JL, Helmreich DL and Schreihofer DA (1993) Modulation of reproductive hormone secretion by nutritional intake: stress signals versus metabolic signals Human Reproduction 8 Supplement 2 162-167

Campfield LA (1997) Metabolic and hormonal controls of food intake: highlights of the last 25 years - 1972-1997 Appetite 29 135-152

Carro E, Pinilla L, Seoane L, Considine RV, Aguilar E, Casanueva FF and Dieguez C (1997) Influence of endogenous leptin tone on the estrous cycle and luteinizing hormone pulsatility in female rats Neuroendocrinology 66 375-377

Casanueva FF and Dieguez C (1999) Neuroendocrine regulation and actions of leptin Frontiers in Neuroendocrinology 20 317-363

Celi P, Martin GB, Blache D, Vercoe PV, Dynes RA and Tellam R (1999) Effects of intracerebral recombinant bovine leptin on voluntary food intake and blood concentrations of glucose and reproductive and metabolic hormones in mature male sheep Proceedings of the Endocrine Society of Australia $\mathbf{4 2} 84$

Chagas L, Blache D, Blackberry MA, Sharma TP and Martin GB (1997) Does glucose infusion affect the CSF concentrations of insulin and gonadotrophin secretion in mature rams Proceedings of the Australian Society for Reproductive Biology 2815

Chagas L, Blache D, Blackberry MA and Martin GB (1999a) Does insulin or leptin mediate the effect of dietary fatty acids on LH pulse frequency in mature male sheep? Proceedings of the Australian Society for Reproductive Biology 3056

Chagas L, Blache D, Blackberry MA, Tellam R, Vercoe PE and Martin GB (1999b) Plasma concentrations of leptin are increased in male sheep fed a diet that stimulates the secretion of LH pulses Proceedings of the Endocrine Society of Australia $\mathbf{4 2} 86$

Chehab FE, Lim ME and Lu RH (1996) Correction of the sterility defect in homozygous obese female mice by treatment with the human recombinant leptin Nature Genetics 12 318-320

Chilliard Y, Bocquier F, Delavaud C, Guerre-Millo M, Bonnet M, Martin P, Faulconnier Y and Ferlay A (1998a) Leptin in ruminants: effect of species, breed, adiposity, photoperiod, beta-agonists and nutritional status Proceedings of the Cornell Nutrition Conference for Feed Manufacturers pp 65-74 Cornell University, Rochester, NY

Chilliard Y, Bocquier F and Doreau M (1998b) Digestive and metabolic adaptations of ruminants to undernutrition and consequences on reproduction Reproduction Nutrition Development 38 131-152

Clarke IJ, Horton RJE and Doughton BW (1990) Investigation of the mechanism by which insulin-induced hypoglycemia decreases luteinizing hormone secretion in ovariectomized ewes Endocrinology 127 1470-1476

Cunningham MJ, Clifton DK and Steiner RA (1999) Leptin's actions on the reproductive axis: perspectives and mechanisms Biology of Reproduction 60 216-222

Dong Q, Bergendahl M, Huhtaniemi I and Handelsman DJ (1994) Effect of undernutrition on pulsatile luteinizing hormone (LH) secretion in castrate and intact male rats using an ultrasensitive immunofluorometric LH assay Endocrinology 135 745-750

Downing JA, Joss J and Scaramuzzi RJ (1995) A mixture of the branched chain amino acids leucine, isoleucine and valine increases ovulation rate in ewes when infused during the late luteal phase of the oestrous cycle: an effect that may be mediated by insulin Journal of Endocrinology 145 315-323

Downing JA, Joss J and Scaramuzzi RJ (1996) The effects of N-methyl-D,Laspartic acid and aspartic acid on the plasma concentration of gonadotrophins, GH and prolactin in the ewe Journal of Endocrinology 149 $65-72$

Downing JA, Joss J and Scaramuzzi RJ (1997) Ovulation rate and the concentrations of LH, FSH, GH, prolactin and insulin in ewes infused with tryptophan, tyrosine or tyrosine plus phenylalanine during the luteal phase of the oestrous cycle Animal Reproduction Science 45 283-297

Dyer CJ, Simmons JM, Matteri RL and Keisler DH (1997a) cDNA cloning and tissue-specific gene expression of ovine leptin, NPY-Y1 receptor, and NPY-Y2 receptor Domestic Animal Endocrinology 14 295-303

Dyer CJ, Simmons JM, Matteri RL and Keisler DH (1997b) Leptin receptor mRNA is expressed in ewe anterior pituitary and adipose tissues, and is differentially expressed in hypothalamic regions of well-fed and feedrestricted ewes Domestic Animal Endocrinology 14 119-28

Ezaki O (1997) Regulatory elements in the insulin-responsive glucose transporter (Glut4) gene Biochemical and Biophysical Research Communications 241 1-6

Finn PD, Cunningham MJ, Pau KYF, Spies HG, Clifton DK and Steiner RA (1998) The stimulatory effect of leptin on the neuroendocrine reproductive axis of the monkey Endocrinology 139 4652-4662

Foster DL, Bucholtz DC and Herbosa CG (1995) Metabolic signals and the timing of puberty in sheep. In The Neurobiology of Puberty pp 243-257 Eds TM Plant and PA Lee. Society for Endocrinology, Bristol

Frayn KN (1996) Metabolic Regulation: A Human Perspective Portland Press Ltd, London

Funston RN, Roberts AJ, Hixon DL, Hallford DM, Sanson DW and Moss GE (1995) Effect of acute glucose antagonism on hypophyseal hormones and concentrations of insulin-like growth factor (IGF)-I and IGF-binding proteins in serum, anterior pituitary, and hypothalamus of ewes Biology of Reproduction 52 1179-1186

Gammeltoft S, Staun-Olsen P, Ottesen B and Fahrenkrug J (1984) Insulin receptors in rat brain cortex. Kinetic evidence for a receptor subtype in the central nervous system Peptides 5 937-944

Gould GW (1997) Facilitative Glucose Transporters Springer, New York

Griffond B, Risold PY, Jacquemard C, Colard C and Fellmann D (1999) Insulin-induced hypoglycemia increases preprohypocretin (orexin) mRNA in the rat lateral hypothalamic area Neuroscience Letters 262 77-80

Harman NG (1991) Energy Metabolism in Rested, Exercised and Over-Fed Sheep Murdoch University, Perth, Western Australia

Henry BA, Goding JW, Alexander WS, Tilbrook AJ, Canny BJ, Dunshea F, Rao A, Mansell A and Clarke IJ (1999) Central administration of leptin to ovariectomized ewes inhibits food intake without affecting the secretion of hormones from the pituitary gland: evidence for a dissociation of effects on appetite and neuroendocrine function Endocrinology 140 1175-1182

Hiney JK, Srivastava V, Nyberg CL, Ojeda SR and Dees WL (1996) Insulinlike growth factor I of peripheral origin acts centrally to accelerate the initiation of female puberty Endocrinology 137 3717-3728

Hoggard N, Mercer JG, Rayner DV, Moar K, Trayhurn P and Williams LM (1997) Localization of leptin receptor mRNA splice variants in murine peripheral tissues by RT-PCR and in situ hybridization Biochemical and Biophysical Research Communications 232 383-387

Horvath TL, Diano S and van den Pol AN (1999) Synaptic interaction between hypocretin (orexin) and neuropeptide $\mathrm{Y}$ cells in the rodent and primate hypothalamus: a novel circuit implicated in metabolic and endocrine regulations Journal of Neuroscience 19 1072-1087

Hötzel MJ, Walkden-Brown SW, Blackberry MA and Martin GB (1995) The effect of nutrition on testicular growth in mature Merino rams involves mechanisms that are independent of changes in GnRH pulse frequency Journal of Endocrinology $14775-85$

Jabbour HN and Lincoln GA (1999) Prolactin receptor expression in the testis of the ram: localisation, functional activation and the influence of gonadotrophins Molecular and Cellular Endocrinology 148 151-161

Kalra SP and Kalra PS (1994) Regulation of gonadotrophin secretion. In The Pituitary Gland: Emerging New Concepts pp 285-307 Ed. H Imura. Raven Press, New York

Kalra SP, Dube MG, Pu SY, Xu B, Horvath TL and Kalra PS (1999) Interacting appetite-regulating pathways in the hypothalamic regulation of body weight Endocrine Reviews 20 68-100

Kauter KG and McFarlane JR (1999) Leptin does not exhibit a circadian rhythm in Merino sheep Proceedings of the Endocrine Society of Australia 4276

Kennedy GC (1953) The role of depot fat in the hypothalamic control of food intake in the rat Proceedings Royal Society of London 140 578-592

King GL and Johnson SM (1985) Receptor-mediated transport of insulin across endothelial cells Science 277 1583-1586

Kobayashi M, Nikami H, Morimatsu M and Saito M (1996) Expression and 
localization of insulin-regulatable glucose transporter (GLUT4) in rat brain Neuroscience Letters 213 103-106

Lebrethon M-C, Vandersmissen E, Gérard A, Parent AS and Bourguignon JP (2000) Cocaine and amphetamine-regulated transcript peptide mediation of leptin-stimulatory effect on the rat gonadotropin-releasing hormone pulse generator in vitro. Journal of Neuroendocrinology 12 383-386

Leloup C, Arluison M, Kassis N, Lepetit N, Cartier N, Ferre P and Penicaud L (1996) Discrete brain areas express the insulin-responsive glucose transporter GLUT4 Molecular Brain Research 38 45-53

Lincoln GA and Short RV (1980) Seasonal breeding: nature's contraceptive Recent Progress in Hormone Research 36 1-52

Lindsay DR, Martin GB and Williams IH (1993) Nutrition and reproduction. In Reproduction in Domesticated Animals pp 459-491 Ed. GJ King. Elsevier, Amsterdam

McFarlane J, Kauter K, Campbell B, Baird D, Leigh A and Scaramuzzi R (1999) Ovarian uptake of leptin and glucose and the role of glucose in the regulation of leptin levels in sheep Proceedings Australian Society for Reproductive Biology 3058

McShane TM, May T, Miner JL and Keisler DH (1992) Central actions of neuropeptide $\mathrm{Y}$ may provide a neuromodulatory link between nutrition and reproduction Biology of Reproduction 46 1151-1157

McShane TM, Petersen SL, McCrone S and Keisler DH (1993) Influence of food restriction on neuropeptide $\mathrm{Y}$, proopiomelanocortin, and luteinizing hormone-releasing hormone gene expression in sheep hypothalami Biology of Reproduction 49 831-839

Martin GB and Walkden-Brown SW (1995) Nutritional influences on reproduction in mature male sheep and goats Journal of Reproduction and Fertility Supplement 49 437-449

Martin GB, Sutherland SRD and Lindsay DR (1987) Effects of nutritional supplements on testicular size and the secretion of LH and testosterone in Merino and Boorola rams Animal Reproduction Science 12 267-281

Martin GB, Tjondronegoro S and Blackberry MA (1994a) Effects of nutrition on testicular size and the concentrations of gonadotrophins, testosterone and inhibin in plasma of mature male sheep Journal of Reproduction and Fertility 101 121-128

Martin GB, Walkden-Brown SW, Boukhliq R, Tjondronegoro S, Miller DW, Fisher JS, Hötzel MJ, Restall BJ and Adams NR (1994b) Nonphotoperiodic inputs into seasonal breeding in male ruminants. In Perspectives in Comparative Endocrinology pp 574-585 Eds KG Davey, RE Peter and SS Tobe. National Research Council of Canada, Ottawa

Martin GB, Fisher JS, Blackberry MA, Boukhliq R, Hötzel MJ, Shepherd K and Walkden-Brown SW (1994c) Nutritional and photoperiodic control of testicular size in Suffolk and Merino rams Proceedings Australian Society of Animal Production 20

Miller DW, Blache D and Martin GB (1995) The role of intracerebral insulin in the effect of nutrition on gonadotrophin secretion in mature male sheep Journal of Endocrinology 147 321-329

Miller DW, Blache D, Boukhliq R and Martin GB (1996) Cerebroventricular concentrations of metabolic fuels and hormones during the nutritional stimulation of gonadotrophin secretion in male sheep 10th International Congress of Endocrinology p. 531 International Society of Endocrinology, San Francisco, CA

Miller DW, Blache D, Boukhliq R, Curlewis JD and Martin GB (1998) Central metabolic messengers and the effects of diet on gonadotrophin secretion in sheep Journal of Reproduction and Fertility 112 347-356

Monget P and Martin GB (1997) Involvement of insulin-like growth factors in the interactions between nutrition and reproduction in female mammals Human Reproduction 2 Supplement 1 33-52

Moriguchi T, Sakurai T, Nambu T, Yanagisawa M and Goto K (1999) Neurons containing orexin in the lateral hypothalamic area of the adult rat brain are activated by insulin-induced acute hypoglycemia Neuroscience Letters 264 101-104

Mounzih K, Lu RH and Chehab FF (1997) Leptin treatment rescues the sterility of genetically obese ob/ob males Endocrinology 138 1190-1193

Murray PJ, Rowe JB, Pethick DW and Adams NR (1990) The effect of nutrition on testicular growth in the Merino ram Australian Journal of Agricultural Research 41 185-189

Nagatani S, Bucholtz DC, Murahashi K, Estacio MA, Tsukamura H, Foster DL and Maeda KI (1996) Reduction of glucose availability suppresses pulsatile luteinizing hormone release in female and male rats Endocrinology $1371166-1170$

Nagatani S, Guthikonda P, Thompson RC, Tsukamura H, Maeda KI and Foster DL (1998) Evidence for GnRH regulation by leptin - leptin administration prevents reduced pulsatile LH secretion during fasting Neuroendocrinology 67 370-376

Oldham CM, Adams NR, Gherardi PB, Lindsay DR and MacKintosh JB (1978) The influence of level of feed intake on sperm-producing capacity of testicular tissue in the ram Australian Journal of Agricultural Research 29 173-179

Peyron C, Tighe DK, Vandenpol AN, Delecea L, Heller HC, Sutcliffe JG and Kilduff TS (1998) Neurons containing hypocretin (orexin) project to multiple neuronal systems Journal of Neuroscience 18 9996-10 015

Plata-Salamán CR (1991) Insulin in the cerebrospinal fluid Neuroscience and Biobehavioral Reviews 15 243-258

Poretsky L and Kalin MF (1987) The gonadotropic function of insulin Endocrine Reviews $8132-141$

Pu S, Jain MR, Kalra PS and Kalra SP (1998) Orexins, a novel family of hypothalamic neuropeptides, modulate pituitary luteinizing hormone secretion in an ovarian steroid-dependent manner Regulatory Peptides $\mathbf{7 8}$ 133-136

Rechler MM and Nissley SP (1986) Insulin-like growth factor (IGF)/ somatomedin receptor subtypes: structure, function, and relationships to insulin receptors and IGF carrier proteins Hormone Research 24 152-159

Ritar AJ, Adams NR and Sanders MR (1984) Effect of lupin feeding on LH, testosterone and testes. In Reproduction in Sheep pp 76-78 Eds DR Lindsay and DT Pearce. Cambridge University Press, Cambridge

Sakurai T, Amemiya A, Ishii M et al. (1998) Orexins and orexin receptors - a family of hypothalamic neuropeptides and $G$ protein-coupled receptors that regulate feeding behavior Cell 92 573-585

Saucier J, Tremblay RR and Dube JY (1983) Changes in insulin binding in rat testis following testosterone and gonadotrophins administration Journal of Receptor Research 3 439-450

Schechter R, Holtzclaw L, Sadiq F, Kahn A and Devaskar S (1988) Insulin synthesis by isolated rabbit neurons Endocrinology 123 505-513

Schechter R, Whitmire J, Wheet GS, Beju D, Jakson KW, Harlow R and Gavin JR (1994) Immunohistochemical and in situ hybridization of an insulin-like substance in fetal neuron cell cultures Brain Research 636 9-27

Schillo KK (1992) Effects of dietary energy on control of luteinizing hormone secretion in cattle and sheep Journal of Animal Science 70 1271-1282

Stewart DE (1992) Reproductive functions in eating disorders Annals of Medicine 24 287-291

Tamura T, Irahara M, Tezuka M, Kiyokawa M and Aono T (1999) Orexins, orexigenic hypothalamic neuropeptides, supress the pulsatile secretion of luteinizing hormone in ovariectomized female rats Biochemical and Biophysical Research Communications 264 759-762

Tena-Sempere M, Pinilla L, González LC, Diéguez C, Casanueva FF and Aguilar E (1999) Leptin inhibits testoterone secretion from adult rat testis in vitro. Journal of Endocrinology 161 211-218

Thiéry JC and Martin GB (1991) Neurophysiological control of the secretion of gonadotrophin-releasing hormone and luteinizing hormone in the sheep - a review Reproduction Fertility and Development 3 137-173

Tjondronegoro S, Miller D, Martin G and Adams N (1992) Prolactin secretion in the male sheep: effect of nutritional status and testicular hormones Abstracts of the 9th International Congress of Endocrinology (Nice) Abstract P070124

Vigersky RA (1984) Hypothalamic hypogonadotropism in weight-lossassociated amenorrhea. In Neuroendocrinology: A Psychiatric Disorder pp 291-300 Eds GM Brown, SH Koslow and S Reichlin. Raven Press, New York

Weigle DS, Duell PB, Connor WE, Steiner RA, Soules MR and Kuijper JL (1997) Effect of fasting, refeeding, and dietary fat restriction on plasma leptin levels Journal of Clinical Endocrinology and Metabolism 82 561-565

Williams LM, Adam CL, Mercer JG, Moar KM, Slater D, Hunter L, Findlay PA and Hoggard N (1999) Leptin receptor and neuropeptide Y gene expression in the sheep brain Journal of Neuroendocrinology 11 165-169

Zapf J, Schoenle E and Froesch ER (1978) Insulin-like growth factors I and II: some biological actions and receptor binding characteristcs of two purified constituents on non-suppressible insulin-like activity in human serum European Journal of Biochemistry 87 285-296

Zoli M, Jansson A, Sykova E, Agnati LF and Fuxe K (1999a) Volume transmission in the CNS and its relevance for neuropsychopharmacology Trends in Pharmacological Sciences $20142-150$

Zoli M, Torri C, Ferrari R, Jansson A, Zini I, Fuxe K and Agnati LF (1999b) The emergence of the volume transmission concept Brain Research Reviews 26 136-147

Zornano A and Camps M (1997) GLUT4 in insulin resistance. In Facilitative Glucose Transporters pp 137-165 Ed. GW Gould. Springer, New York 